\title{
Persistent Hyperplastic Primary Vitreous
}

National Cancer Institute

\section{Source}

National Cancer Institute. Persistent Hyperplastic Primary Vitreous. NCI Thesaurus. Code C161554.

A cong enital abnormality of the eye caused by failure of regression of the primary vitreous and hyaloid vasculature anteriorly and/or posteriorly. 